\title{
Neue Bänke im Palmengarten
}

Am 18. Mai 2017 sind drei neue Bänke an den Palmengarten übergeben worden und haben am Oktogon-Brunnen ihren Platz gefunden. Gespendet wurden diese von Mitgliedern der Freunde des Palmengartens, die damit ihre Verbundenheit mit dem Palmengarten deutlich zeigen.

Wer sich angesprochen fühlt und auch eine Bank spenden möchte, kann sich gerne an die Freunde des Palmengartens wenden (E-Mail: info@palmengartengesellschaft.de oder telefonisch donnerstags von 15.30 bis 17.00 Uhr unter (069) 745839).

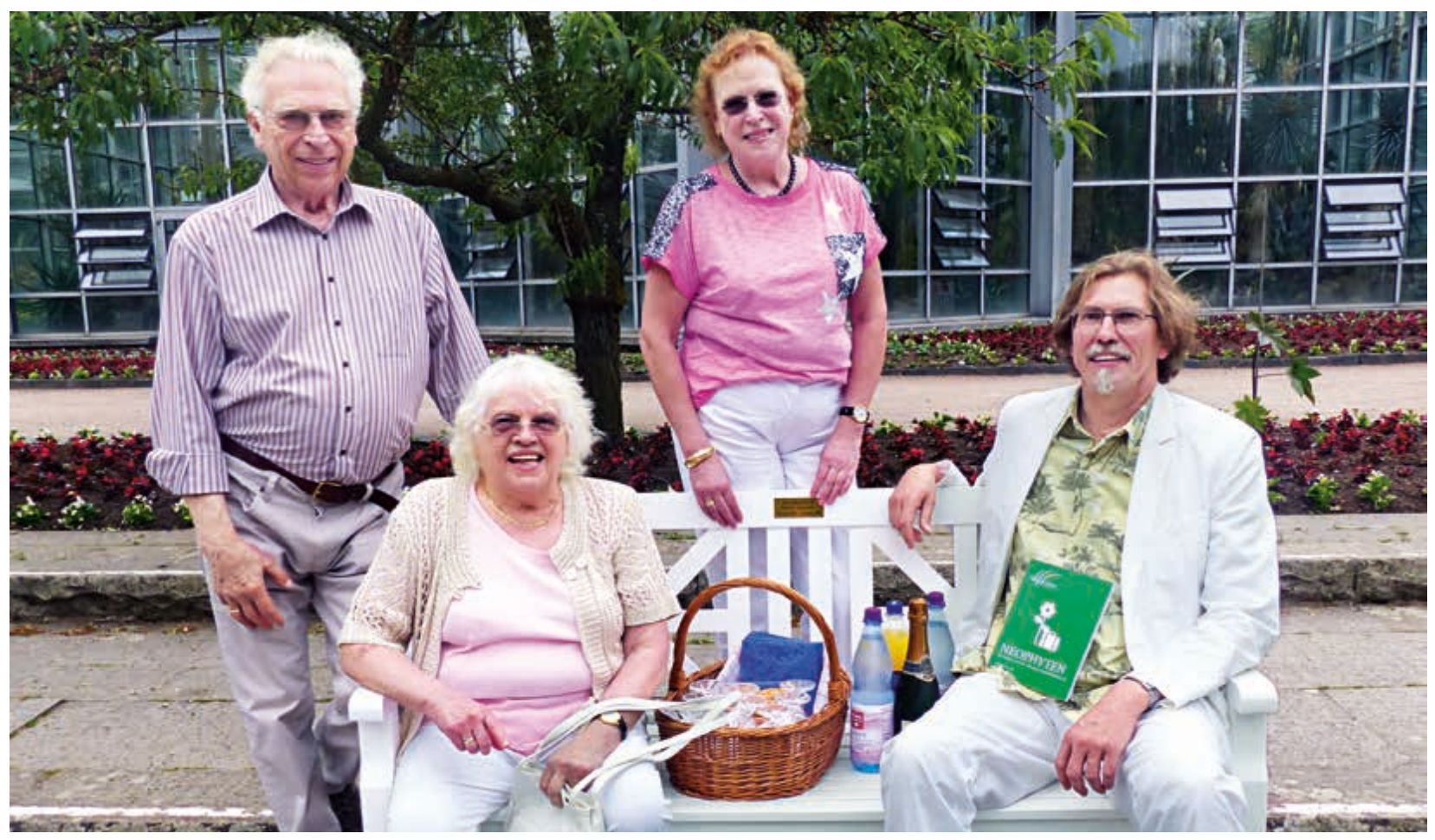

Abb. 1: Einweihung der neuen Bank.

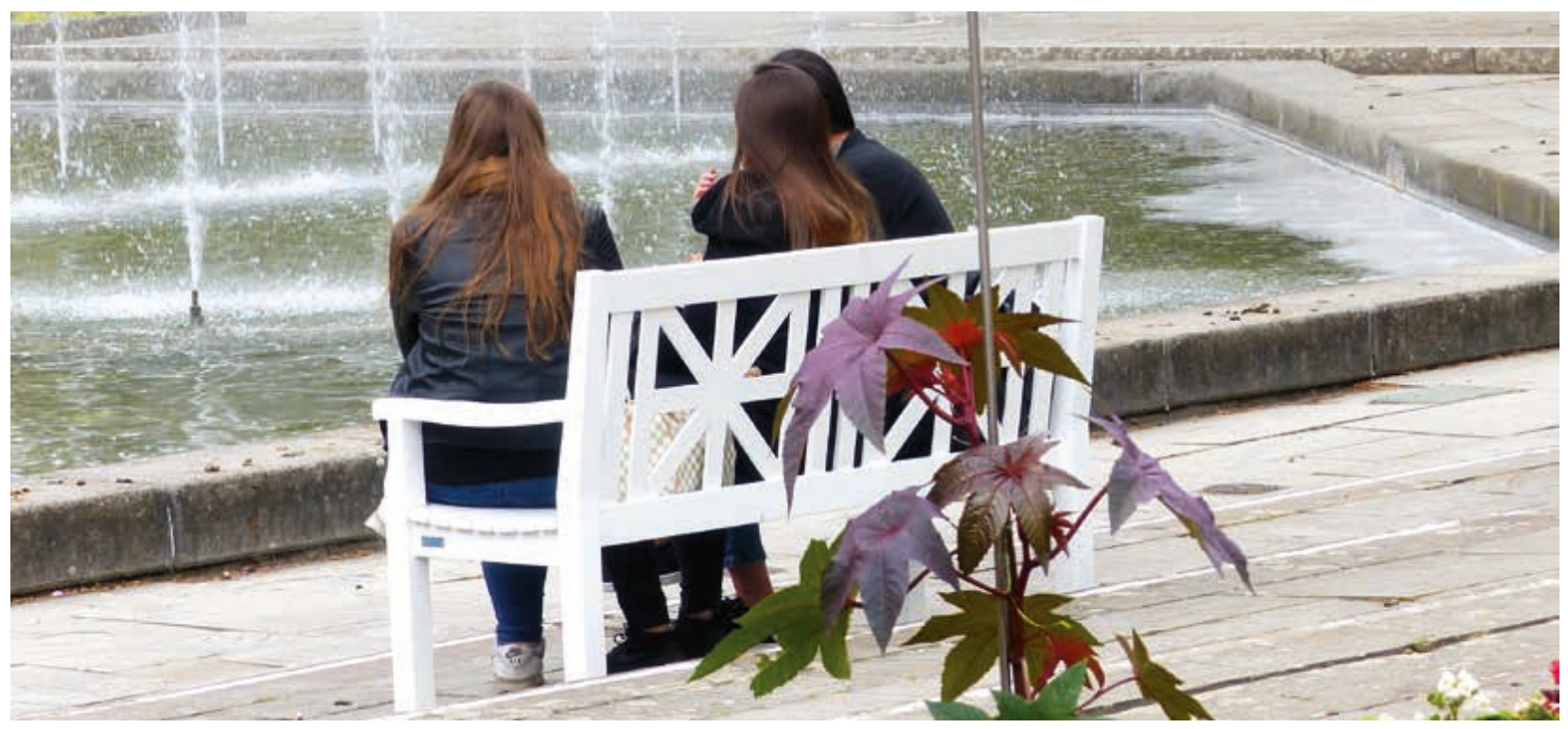

Abb. 2: Die Bänke laden zum Verweilen ein. 